\title{
The disruptive innovation and the pre-texts methodology
}

\author{
A inovação disruptiva e a metodologia pré-textos
}

\author{
Camila Maciel de Oliveira' (1) $\mid$ camilamacieloliveira@gmail.com \\ Mercedes Balcells ${ }^{1,2}$ (1) merche@mit.edu \\ Doris Sommer ${ }^{3}$ (D) dsommer9@gmail.com
}

\begin{abstract}
Introduction: The experience report describes the protocol used in one of the activities carried out during the initiative aimed at the search for health impact solutions through disruptive innovation - "IDEA ${ }^{2}$ Global, Guidance and transforming connections for innovators in medical technology", in May 2019, at the Institute of Medical Engineering and Science, Massachusetts Institute of Technology (IMES MIT).

Experience report: The Pre-Texts methodology was chosen to stimulate creativity and instill the curiosity inherent in the search for solutions to complex problems, through the reading of a challenging text and related activities in a workshop format. Bringing together professionals from various segments and nationalities, the two-hour and forty-five-minute period was the time spent on the workshop inspired by practices from some Latin American countries.

Discussion: Through observation, it was observed that participants were engaged and fascinated by hands-on activities, amid the active reading of a text on neural connections in creative processes. The feedback from the evaluation on the workshop confirmed the facilitators' impression.

Conclusion: The Pre-Texts methodology is a strategy that can be applied in heterogeneous groups and can include skills such as creativity and collaboration. Thus, the use of this methodology should be encouraged in other similar situations.
\end{abstract}

Keywords: Innovation; Interdisciplinary Communication; Methodology; Medical Education.

\section{RESUMO}

Introdução: O relato de experiência descreve o protocolo utilizado em uma das atividades realizadas durante a iniciativa destinada à busca por soluções de impacto em saúde através da inovação disruptiva - "IDEA Global, Orientação e conexões transformadoras para inovadores em tecnologia médica", em maio de 2019, no Instituto de Engenharia Médica e Ciência, Massachusetts Institute of Technology (IMES MIT).

Relato de Experiência: A metodologia Pré-Textos foi escolhida para estimular a criatividade e instigar a curiosidade inerentes à busca por soluções de problemas complexos, através da leitura de um texto desafiador e atividades relacionadas, em formato de workshop. Reunindo profissionais de vários segmentos e nacionalidades, o período de duas horas e quarenta e cinco minutos foi o tempo dispensado ao workshop inspirado em práticas oriundas de alguns países da América Latina.

Discussão: Por meio da observação participante, constatou-se que os partícipes se mostraram entusiasmos e engajados por atividades "mão na massa", em meio a leitura ativa de um texto sobre conexões neurais em processos criativos. A devolutiva da avaliação sobre o workshop confirmou a impressão dos facilitadores.

Conclusão: A metodologia Pré-Textos é uma estratégia passível de aplicação em grupos heterogêneos, podendo contemplar habilidades como a criatividade e a colaboração. Assim, estimula-se a utilização desta metodologia em outras situações semelhantes.

Palavras-chave: Inovação; Comunicação Interdisciplinar; Metodologia; Educação Médica.

${ }^{1}$ Institute for Medical Engineering and Science, Massachusetts Institute of Technology, Cambridge, Massachusetts, USA.

${ }^{2}$ Bioengineering Department, Institut Quimic de Sarria, Ramon Llull Univ, Barcelona, Spain.

${ }^{3}$ Romance Languages and Literatures and of African and African American Studies, Harvard University, Cambridge, Massachusetts, USA.

Chief Editor: Rosiane Viana Zuza Diniz.

Associate Editor: Pedro Tadao Hamamoto Filho.

Received on 07/14/20; Accepted on 03/11/21.

Evaluated by double blind review process. 


\section{INTRODUCTION}

The diverse characteristics that constitute a human being are usually influenced by two unavoidable conditions. Genetic and environmental factors are considered to be essential, not only in relation to the incidence of diseases, but also in terms of aspects related to creativity'.

Especially in recent years, the study of genes that determine the formation of a neurotransmitter called dopamine, the description of sets of anatomical structures in the brain responsible for creativity and the environment in which the individual is placed have been objects of study ${ }^{1,2}$. This has happened due to the need to understand the mechanisms involved in the creative process, essential to the act of innovating.

Disruptive innovation, in turn, is defined as the transformation of a technology, product or service into something new, simpler, more convenient and accessible ${ }^{3}$. In a complementary way, co-creation has been used for some years as a strategy by several market segments. By definition, the verb 'co-create' is understood as a way to innovate through collaboration, bringing together multidisciplinary individuals and the concerned parties in search of a common goal ${ }^{4}$.

Concepts such as disruptive innovation and co-creation

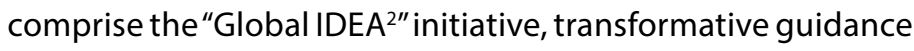
and connections for medical technology innovators ${ }^{5}$. The pretexts methodology, on the other hand, has been applied in different situations and audiences supported by three main pillars, such as stimulating innovation in education, reading and citizenship ${ }^{6}$. However, it has been reported that other skills are subject to consideration, depending on the need and interest of the group or the directions given by the text and proposed activities ${ }^{6}$.

Therefore, in this experience report, the aim was to demonstrate how the Pre-Texts methodology protocol was applied to a heterogeneous group, including enterprising physicians, to stimulate creativity and instigate curiosity, during the first face-to-face meeting of "IDEA² Global", in 2019.

\section{EXPERIENCE REPORT}

The "IDEA" Global, Transforming Guidance and Connections for Innovators in Medical Technology" is an initiative aimed at finding solutions that have an impact on healthcare through disruptive innovation. The projects are submitted for appraisal by internal and external evaluators in relation to the institution, in the beginning of each year (March or April). It is held annually through face-to-face and remote seminars and tutorials, over the course of six months. These seminars are implemented by researchers from the Institute of Medical Engineering and Science, Massachusetts Institute of Technology (IMES MIT) and partner mentors.
The aim of this action is to support the improvement of projects previously initiated by Latin American, North American and European enterprising scientists.

In 2019, the Pre-Texts ${ }^{6}$ methodology was one of the activities chosen to stimulate creativity in challenging situations and in collaboration experimentation during "IDEA ${ }^{2}$ Global". Both skills - creativity and collaboration - would be critical in the months that followed for those participants engaged in solving complex problems and involved in the disruptive innovation process.

\section{The methodology}

The Pre-Texts methodology was inspired by Brazilian authors such as Paulo Freire and Augusto Boal and by practices created in some Latin American cultures ${ }^{6}$. Through simple proposals, the guidelines are explained in their entirety from the beginning of the workshop. And, to ensure relaxation and rapport, the opening of the workshop always takes place with an activity called 'icebreaker', for instance, the throwing of paper balls for the presentation dynamics, as described below.

During the entire workshop period, the arrangement of the group in a circle is a mandatory premise, so that everyone can see and be seen. Other rules are important for the moments of dialogue and reflection. For instance, a participant will have the opportunity to speak a second time if everyone has already spoken at least once. Another interesting strategy that constitutes the method is that the "neighbors" (people on each participant's side) are checked to make sure that everyone has expressed their point of view. The 'time out' hand gesture can be used by any of the participants to signal when someone's speech is extending beyond what was proposed, as succinct and direct sentences are suggested.

The material to be used in practical activities is available on a table or even on the floor, aiming to decentralize the source and encourage autonomy, not being distributed or given to the participants.

Prior to each activity, the following sequence is followed:

1. the disclosure of the title and what inspired the construction of that activity

2. recommendations to carry out that practice

3. the time limit for the development

During the first activity, the text is read aloud by one of the participants who volunteered for the task, which was not previously given to the others. Only after the reading the text is made available to those interested in it. Usually, all participants seek the text for the second reading due to the concern for the adequate preparation of the reasoning that will be revealed in the discussion circle. Only a few minutes are available for individual reading. 
At the end of each developed activity, all participants share their reflections on what was done in the previous moment. The reflection is used to intertwine creative practice and critical thinking about the text being analyzed. The discussion starts with the phrase "What did we do?".

\section{Choosing the text}

The text is the main reason (the cause) for the subsequent development of all other activities.

The choice of text is made by the facilitator, prior to the workshop, and needs to be done carefully, to ensure that the content is appropriate to the group's intellectual level, so the participants feel challenged, which ensures reader/participant engagement. Therefore, it is not advisable for the text to be either easy or too difficult ${ }^{6,7}$.

It is recommended that all participants be on an equal footing, i.e., the text should not favor anyone and should not have been previously read by any member.

\section{Description of performed activities}

1. The warm-up (the "icebreaker") was carried out to strengthen relationships in a relaxed manner. At this time, we provided a small newspaper ball and clarified the rules of the game: whoever received the ball would say their name and their profession. Within minutes, other balls were gradually included in the game. Generally speaking, when several balls are thrown at the same time, the participants' attention needs to be refined or enhanced.

2. Making a book cover using recyclable materials. It was one of the ways to demonstrate how to build or rebuild from available materials, mimicking situations experienced by people in developing countries. Faced with the scarcity of resources, creativity is challenged.

3. Text reading performed simultaneously with manual work. We based ourselves on the assumption that the attention given to the text under this condition could be enhanced. A volunteer then read aloud while their colleagues worked on making the cover of the book.

4. Creation of questions to and from the text. Its purpose is to engage the reader, making them not only the content recipient, but actively participate in the reading process. Each person's questions were written on a piece of paper, read aloud, and then hung on a string. At a second moment, all the participants went to the string and each one chose a question they would like to answer. Back to their places, the answer was written and shared with the entire group.

5. Representation, through gestures and body dynamics. It was carried out based on the choice, in pairs or trios, of an expression contained in the text. It was advised that the arrangements should integrate people who did not know each other previously. Each group then chose the expression of the text they would like to imitate. After choosing and arranging for the performance, while one group acted, everyone else tried to guess the chosen expression.

Through the observation, we verified the participants' engagement with and fascination for hands-on activities (photo 01 ), amid active reading of a text about neural connections in creative processes ${ }^{2}$. The feedback from the workshop evaluation confirmed the facilitators' impression.

\section{Creativity as a skill}

Currently, the world requires strategies for the development of students who can envision possibilities beyond the obvious, both professionally and in their personal life $^{8}$, and the Pre-texts methodology potentially influences this skill. This strategy was chosen to be used in "IDEA² Global", so that participants would recognize the importance of "thinking outside the box".

Regarding brain structures, the area responsible for art-related creativity is different from that used for problem solving ${ }^{2}$. In the same methodology, stimuli are generated in different areas of the brain, potentially influencing different fields of action. Thus, the Pre-texts methodology contemplates two types of creative processes - related to art and problem solving - in a coordinated and simultaneous manner throughout its entire process.

During the discussion circles, exposure to different perspectives stimulates the generation of creative ideas ${ }^{9}$. Additionally, the absence of judgment by facilitators or colleagues as a rule contributes to freedom of thought and creation, as reported in the literature?.

We use artistic activities - such as making book covers while listening to the reading of a challenging text, for instance - as a trigger to stimulate creative thinking. On the other hand, the dynamics involving different bodily expressions, coordinated in a group, can be considered here as the product of the search for solutions.

Through the analysis of different phases of careers considered to be creative, Lu Liu et. al. observed that, during the hot streaks of scientists and artists, there was no detectable change in relation to productivity, considering 
the fundamental role of endogenous changes in individual creativity in this period ${ }^{10}$. They defined the term 'hot streaks' as the moment in their professional life when individual performance is substantially superior to their typical performance, characterized by the phase in which "'winning begets more winnings"10.

Some of the essential characteristics for the development of an individual's creative potential include intellectual skills, such as problem definition and insightful thinking, in addition to the production of new ideas and intrinsic motivation ${ }^{2}$. Every day, the relevance of specific characteristics conferred on scientists who will need to face situations such as pandemics, world poverty or climate change becomes increasingly clearer. Dynamicity and thinking "outside the box" will be great allies when solving complex problems imposed by unavoidable situations such as the abovementioned ones ${ }^{8,11}$. It is essential that participants understand the need to engage in multidisciplinary teams, developing skills capable of predicting changes and positively influencing colleagues around them ${ }^{8}$.

In the contemporary scenario, creativity is essential to influence disruptive processes. However, in order to do this, countless hours of work inside four walls will not be enough.

\section{CONCLUSIONS}

The experience allowed us to reaffirm that there is no single methodology to stimulate the development of skills such as creativity and/or problem solving; however, there are favorable or potential paths. The experience reported herein used the Pre-Texts pedagogical method, recognized in Humanities education, transposed to education for a multidisciplinary group, including enterprising physicians. The methodology questions the learning, teaching, researching and being an expert. In this report, it was possible to demonstrate that the Pre-Texts methodology is a strategy that can be applied in heterogeneous groups and may include skills such as creativity and collaboration.

\section{AUTHORS' CONTRIBUTION}

Camila Maciel de Oliveira: data analysis and interpretation, data collection and manuscript writing. Mercedes Balcells: supervision and overall responsibility for the study. Doris Sommer: study conception and design, methodology and validation and critical review of the manuscript.

\section{CONFLICTS OF INTEREST}

The authors declare no conflicts of interest.

\section{SOURCES OF FUNDING}

M.B. was partially funded by Spain Minister of Economy (SAF2017-84773-C2-1-R), Fundacion Empreses IQS and the Global CoCreation Lab, Inc (Miami, FL).

\section{REFERENCES}

1. Heilman KM. Possible brain mechanisms of creativity. Arch Clin Neuropsychol. 2016;31(4):285-96.

2. Schuler $A L$, Tik $M$, Sladky R, Luft CD, Hoffmann $A$, Woletz $M$, et al. Modulations in resting state networks of subcortical structures linked to creativity. Neurolmage. 2019;195:311-9.

3. Bencke FF, Gilioli RM, Royer A. Inovação disruptiva: uma análise das pesquisas empíricas publicadas no Brasil| Disruptive innovation: an analysis of the empirical research published in Brazil. Revista Brasileira de Gestão e Inovação. 2017;5(2):159-80.

4. Greenhalgh T, Jackson C, Shaw S, Janamian T. Achieving research impact through co-creation in community-based health services: literature review and case study. Milbank Q. 2016;94(2):392-429.

5. MIT. Transformative mentorship and connections for medical technology innovators (IDEA2); 2019. [acesso em 15 mai 2020]. Disponível em: https:// idea2.mitlinq.org/.

6. Sommer D. The work of art in the world: Civic agency and public humanities. Duke University Press; 2013.

7. Rancière J. O mestre ignorante: cinco lições sobre a emancipação intelectual. Autêntica; 2011.

8. Lechler R. Diversity, creativity, and flexibility will be needed from the next generation of medical scientists. Lancet. 2017;389 Suppl 1:S1.

9. Ezzat H, Camarda A, Cassotti M, Agogué M, Houdé O, Weil B, et al. How minimal executive feedback influences creative idea generation. PloS One. 2017;12(6):e0180458.

10. Liu L, Wang $Y$, Sinatra R, Giles CL, Song C, Wang D. Hot streaks in artistic, cultural, and scientific careers. Nature. 2018;559(7714):396.

11. Resnick M, Robinson K. Lifelong kindergarten: Cultivating creativity through projects, passion, peers, and play. MIT Press; 2017. 